\title{
Художественный некрополь как объект историко-архитектурного наследия: проблемы сохранения (российский и европейский опыт)
}

\author{
Ю.А.Логинова, МАРХИ, Москва
}

Скульптура некрополей XVIII и других столетий, которая представлена многими выдающимися произведениями, подвергаясь воздействию неблагоприятной окружающей среды, находится под угрозой необратимых трансформаций и даже гибели. Затронутая в статье тема, несмотря на свою актуальность, в настоящее время не получила должного внимания специалистов в области реставрации. В статье сделана попытка соединить теоретические изыскания с большим практическим опытом многих поколений реставраторов в области реставрации мемориальной скульптуры. Не случайно в качестве центрального памятника был выбран ансамбль некрополя Александро-Невской лавры в Санкт-Петербурге. В истории его создания, реорганизации, музеефикации и реставрации, осуществлявшихся в разные периоды его существования, отразилось многообразие проблем, связанных с изучением памятников, в которых архитектура, скульптура, ландшафтное искусство и эпиграфика составляют неразрывное целое. Кроме того, в статье рассматриваются не только отечественные примеры, но и такие мемориальные ансамбли, как кладбище Асситен в Бергене, в Норвегии, кладбища XIX века в Берлине, кладбища Ла-Виллетта в Парме и история их эксплуатации и сохранения.

Ключевые слова: реставрация, консервация, некрополь, монастырь, захоронение, памятник.

Artistic Necropolis as an Object of Historical and Architectural Heritage: Conservation Problems (Russian and European Experience)

Yu.A.Loginova, MARKHI, Moscow

Sculpture of necropolises of the 18th and other centuries, which is represented by many outstanding works, exposed to the effects of an unfavorable environment, is in danger of irreversible transformation and even destruction. The topic touched upon in the article, despite its relevance, has not currently received proper attention from specialists in the field of restoration. The article combines theoretical research with the extensive practical experience of many generations of restorers in the field of restoration of memorial sculpture. It is no coincidence that the ensemble of the necropolis of the Alexander Nevsky Lavra in St. Petersburg was chosen as the central monument. The history of its creation, reorganization, museumification, and restoration, carried out in different periods of its existence, reflects the variety of problems connected with the study of monuments of this kind, in which architecture, sculpture, landscape art, and epigraphy form an inseparable whole. In addition, the article examines not only domestic examples but also such memorial ensembles as Assyten Cemetery in Bergen, Norway, 19th-century cemeteries in Berlin, La Villette Cemetery in Parma and the history of their exploitation and preservation. The information presented in this article may be useful for historians of architecture, necropolis, and restoration artists.

Keywords: restoration, conservation, necropolis, monastery, burial place, monument.

Каменная скульптура - из мрамора и известняка, из песчаника и гранита, - её сохранность в условиях экспонирования на открытом воздухе волнует многих специалистов реставрационного сообщества по всему миру, и «всё чаще звучат слова о том, что "срок пребывания" старинных мраморов под открытым небом уже истёк» [1, с. 9].

Данный вопрос также поднимается и в зарубежной литературе. В книге «Воздействие загрязнения воздуха на культурное наследие» (Нью-Йорк, 2009) в начале предисловия автор отмечает, что «наше промышленное развитие оставило нам в наследство безликие статуи и почерневшие здания, на ремонт и консервацию которых уйдёт много лет, даже если уровень загрязнения будет в достаточной степени снижен» [2, p. V].

Особенно актуальна проблема сохранения каменной скульптуры для памятников исторических некрополей. Стоит отметить, что раздел мемориального искусства представляет значительный интерес. Создание мемориальных памятников и комплексов имеет большое значение в культурном развитии, так как это, прежде всего, символ исторической памяти, а её утрата - это общенациональная проблема. В связи с этим их реставрация - это выстраивание особых отношений с историческим временем, его воскрешение и сохранение.

Интересно рассмотреть вопрос сохранения мемориального наследия с двух сторон. Во-первых, проанализировать особенности реставрационных работ, а во-вторых, изучить аспекты современного бытования и включения исторических некрополей в городскую жизнь.

Некрополь XVIII века - старейшее в Петербурге кладбище, созданное при закладке Невского монастыря, оно было местом погребения лиц, принадлежащих к при- 
вилегированным сословиям. В.П. Головин в своей книге «0т амулета до монумента» пишет: «Старый монастырь занимает особое место среди историко-художественных достопримечательностей Санкт-Петербурга. Он известен не только как комплекс замечательных архитектурных сооружений и скульптурных коллекций 18-19 веков. Вместе с филиалом музея - некрополем "Литераторские мостки" - Свято-Троицкая Александро-Невская Лавра представляет собой русский пантеон, знаменитый многими "великими" могилами» [3, с. 5-6].

История кладбища начинается с 1717 года (хотя отдельные захоронения делались и раньше), когда здесь была похоронена любимая сестра Петра I царевна Наталья Алексеевна, а затем и его сын, царевич Пётр. Над их могилами была возведена небольшая часовня во имя Воскрешения святого Лазаря, от которой всё кладбище получило название Лазаревского. Через несколько лет останки Натальи Алексеевны и Петра Петровича были перенесены в Благовещенскую церковь и перезахоронены в самой почётной - алтарной - части. Благовещенская церковь стала первой царской усыпальницей Петербурга. С самого начала Лазаревское кладбище получило чрезвычайно высокий статус. При Петре I для совершения там захоронения требовалось личное разрешение императора.

Основная часть могил на Лазаревском кладбище относится к XVIII столетию, хотя хоронить продолжали ещё в XIX и даже в XX веках. Одним из последних стало захоронение в 1915 году выдающегося государственного деятеля графа С.Ю. Витте.

За всю свою историю кладбище пережило непростые времена. В 1919 году кладбище было закрыто для погребений, и только в начале $1930-x$ годов на его основе стал создаваться музей художественных надгробий (рис. 1).

Современный Музей городской скульптуры в СанктПетербурге является преемником Музея-некрополя, ос-

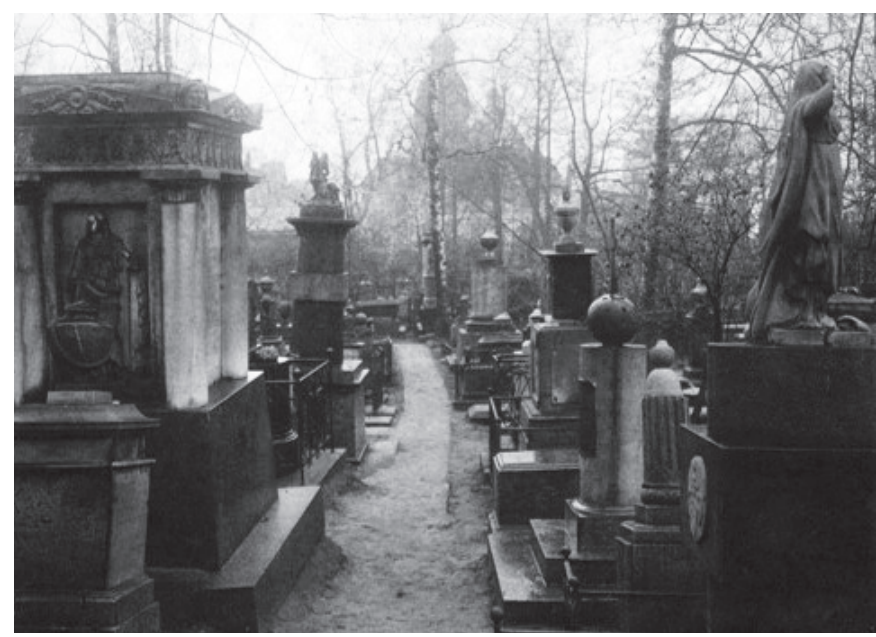

a)

Puc. 1. Некрополь XVIII века. Общий вид: а) фото Н.В. Успенского 12 июня 1940 года (источник - архив ГмГС, г. СанктПетербург). Слева памятники Потемкиной-Закревской, Воронихину и др.; б) наши дни. Фото Ю.А. Логиновой нованного в 1932 году с целью сохранения уникального собрания мемориальной скульптуры XVIII - начала XX века. Президиум Ленсовета 28 июля 1932 года объявил Лазаревское кладбище бывшей Александро-Невской лавры Заповедником-музеем, присоединив к его территории соседнее Тихвинское и территорию, на которой располагалась Благовещенская церковь для создания в них музея надгробной скульптуры. В 1935 г. на правах филиала был музеефицирован некрополь «Литераторские мостки».

Многочисленные утраты и разрушения памятников некрополей были связаны с реорганизацией кладбищ, значительные повреждения были получены во время Великой Отечественной войны. Находящиеся на открытом воздухе в условиях агрессивной городской среды, художественные надгробия подвергаются интенсивному процессу физикохимического выветривания и биологической коррозии, что приводит к появлению характерных форм и видов разрушения камня, таких как эрозия, деструкция, растрескивание, расслоение и осыпание частиц каменного материала, образование чёрных корок, атмосферные и грязевые отложения, биообрастание камня.

Такие непростые, порой трагичные условия исторического существования некрополей музея вызывают необходимость осуществления целого комплекса мер по возрождению утраченных памятников, сохранению и предотвращению их дальнейшего разрушения.

0бзор реставрационной деятельности Государственного музея городской скульптуры (ГМГС), начиная с 1950-х годов, позволяет сделать вывод о том, что работа по сохранению надгробных памятников ведётся по нескольким направлениям.

Прежде всего, это реставрация и консервация памятников на месте их нахождения. Кроме того, необходимой мерой является музеефикация оригиналов и замена их копиями.

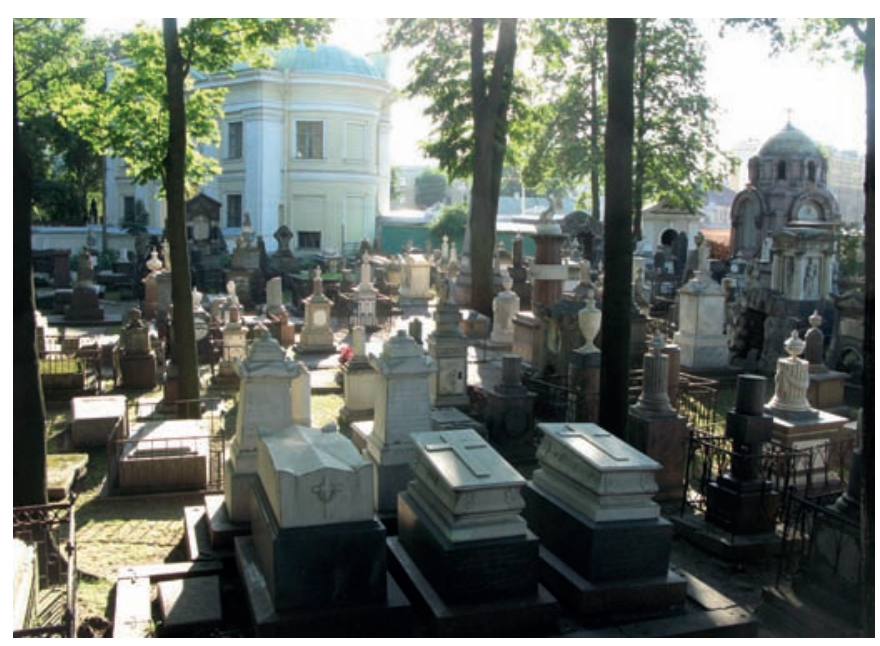

б) 
Большое внимание уделяется воссозданию утраченных скульптурных элементов надгробных сооружений - портретных рельефов, бюстов, а также досок с надписями.

Выбор того или иного способа диктуется рядом факторов, среди которых степень аварийности состояния объекта, особенности техники создания, историческая и художественная ценность того или иного памятника.

Так, необходимость музеефикации скульптурных элементов надгробных сооружений, замена их копиями или воссоздание становится очевидной, когда утраты значительно обедняют художественную выразительность памятника как целостного архитектурно-скульптурного комплекса или теряется научно-просветительский аспект, как, например, в случае разрушения досок с текстом.

Примером необходимости такого комплексного подхода является надгробие С.А. Строгановой (М.И. Козловский, 1802, мрамор, гранит), где наиболее значительным разрушениям подверглись скульптурные изображения, выполненные из мрамора. Портретный барельеф С.А. Строгановой был воссоздан в 1969 году И.В. Крестовским, в 1967 году скульптуры перенесены в Лазаревскую усыпальницу для предотвращения их дальнейшего разрушения [4, с. 271].

Нельзя не упомянуть и о надгробии М.И. Козловского (В.И. Демут-Малиновский, 1803, мрамор), где в 1955 году был воссоздан утраченный барельеф с портретом М.И. Козловского, а в 1971 году - рельеф с фигурой Гения смерти заменён копией, вырубленной из мрамора, оригинал находится в Благовещенской усыпальнице. Портретный бюст А.В Мещерского (Я. Земельгак, 1782, мрамор) был воссоздан по иконографическому материалу в 1965 году скульптором Г.С. Ястребенецким.

Работа по воссозданию разрушенного во время Великой Отечественной войны скульптурного бюста В.Н. Асенковой была выполнена в 1955 году мастером Д.А. Спришиным, вы-

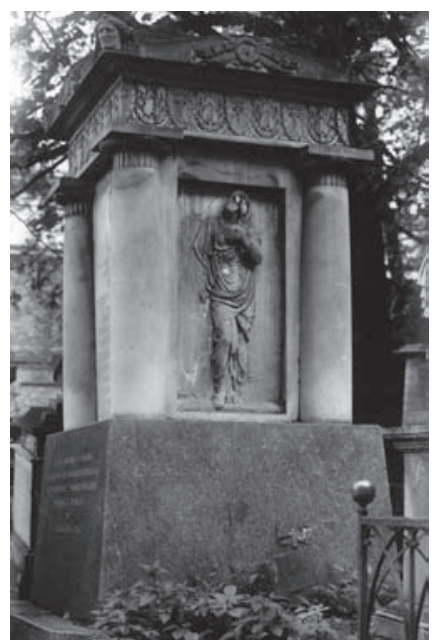

a)

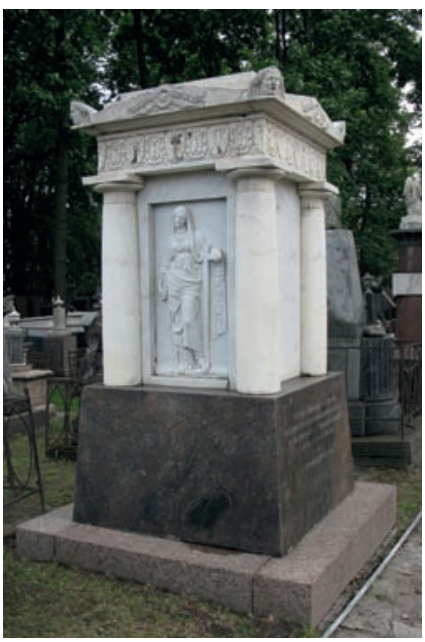

б)
Pис. 2. Надгробие П.А. Потёмкиной: а) фото Н.В. Успенского. 12 июня 1940 года (источник - архив ГМГС, г. СанктПетербург); б) после реставрации. 2007 год рубленный из мрамора бюст был установлен на постаменте существовавшего некогда надгробного сооружения. Работы по восстановлению проводились, конечно же, не только с мраморной скульптурой. Бронзовые портретные бюсты и медальоны были воссозданы на надгробиях М.А. Балакиревой (Ф.Г. Бернштам, Н.А. Пыпина, 1914; барельеф - Н.В. Дыдыкин, 1948-1950; габбро, бронза), Е.А. Боратынского (1840-е; барельеф - Н.В. Дыдыкин, 1950; гранит, бронза) и ряде других памятников.

Сегодня многочисленные воссозданные скульптурные произведения являются не только важными художественными акцентами надгробных памятников, для которых они высекались в мраморе или отливались в бронзе, но и представляют собой часть творческого наследия скульпторов 1950-1970-х годов, работавших над их созданием.

В этот период копирование разрушающихся мраморных скульптур было единственной эффективной мерой сохранения мраморных оригиналов от агрессивного воздействия природных факторов. Технологии укрепления и защиты мрамора, находящегося на открытом воздухе, только разрабатывались. В этом отношении интересен опыт реставрации ряда находившихся в крайне неудовлетворительном состоянии мраморных памятников, в частности мраморного мавзолея П.А. Потёмкиной (И.П. Мартос, 1810-е, мрамор, гранит, рис. 2).

Очистка и укрепление аллегорических рельефов «Вера», «Надежда» и «Любовь» были выполнены с 1951 по 1954 год Е.А. Румянцевым¹, заведующим реставрационной мастерской скульптуры и предметов прикладного искусства Государственного Эрмитажа (ГЭ) [5]. Укрепление проводилось методом «глубинной пропитки» с применением поливинилбутираля ${ }^{2}$, ректифицированного спирта и бензола, из которых готовился так называемый «бутвар». Как следует из отзыва директора Государственного музея городской скульптуры Г. Нетунахиной, «все пропитанные (закрепленные) памятники, несмотря на резкие изменения температуры, сильные морозы и обильные дожди, вполне сохранились, в то время как незакреплённые продолжают разрушаться». О внимании, с которым сотрудники ГМГС относились к сохранению памятников, свидетельствует развёрнутый план работ по реставрации на 1952 год, где представлен раздел «Консервация», предписывающий «укрепление мраморных памятников XVIII-XIX веков, находящихся в крайне аварийном состоянии», путём пропитки их раствором синтетических смол. Среди памятников, указанных в этом разделе - надгробие Е.С. Куракиной (рис. 3), барельеф Н.И. Гнедича, надгробие М.И. Козловского. Все эти произведения тем не менее впоследствии будут

${ }^{1}$ Архив ГМГС. Инв. № 498. П-64. Л.6, 7. Дело о надгробии Прасковьи Андреевны Потёмкиной-Закревской.

${ }^{2}$ В настоящее время поливинилбутираль марок КБ и ЛА применяется в Лаборатории научной реставрации скульптуры и цветного камня ГЭ для склейки и мастиковки памятников из камня музейного хранения. 
перенесены в музей, заменены копиями, а оригиналы отреставрированы с применением кремнийорганических материалов.

В отношении же каменных архитектурных элементов надгробий применялся другой подход. 0 многочисленных попытках восстановить декоративные особенности различных пород цветного мрамора, теряющего полированную фактуру и разрушающегося под воздействием атмосферы, свидетельствуют следы реставрационных работ, в ходе которых использовались мастиковка на основе эпоксидных смол с каменным наполнителем, перешлифовка, механическая расчистка поверхности, что было характерно и для реставрации каменной облицовки фасадов Мраморного дворца в 1951-1955 годы [6; 5, с. 312].

Если исследование и систематизация природных форм и видов разрушения каменных надгробий успешно проводится в последние годы [6], то изучение приёмов и методов предшествующих реставраций может стать темой отдельных исследований, необходимых для понимания особенностей хранения памятников на открытом воздухе (рис. 4).

Рассматривая и анализируя вопрос сохранения мемориального наследия, нельзя говорить только об особенностях реставрационных работ, важно изучить аспекты современного бытования и включения исторических некрополей в городскую жизнь, так как это также один

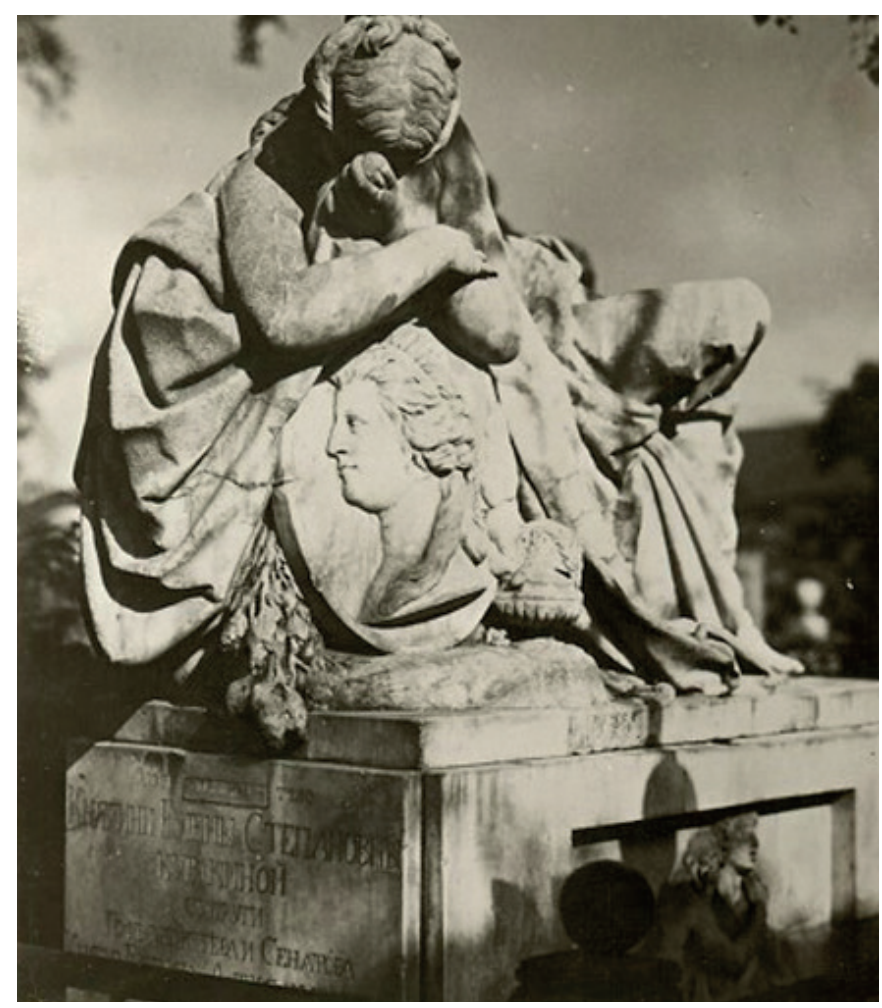

a)

Pис. 3. Надгробие. Е.С. Куракиной: а) фотография, фиксирующия состояние памятника в 1933 году (источник: Архив ГмГС); в) мраморный подлинник. После реставрации перенесён и хранится в Благовещенской усыпальнице Александро-Невской Лавры. Санкт-Петербург из важнейших механизмов сохранения мемориального наследия.

Обращаясь к европейскому опыту сохранения мемориальных памятников, стоит отметить, что во многих странах современное отношение к историческим некрополям абсолютно не совпадает с российским.

К примеру, рассмотрим историю кладбищ в Норвегии, в городе Бергене. Кладбища здесь почти такие же древние, как и церкви. На самом деле все средневековые церкви Бергена были построены в XII веке, как и пять исторических кладбищ, где в последние годы были проведены реставрационные работы и для населения был обеспечен более широкий доступ. Одно из кладбищ, Ассистенткиркегарден, созданное в 1837 году, используется сегодня уже не как кладбище, а как общественный парк. Здесь похоронены многие известные люди, в том числе скрипач и композитор Оле Булль. Ассистенткиркегарден вместе с другими историческими кладбищами в центре Бергена было недавно восстановлено, и местные власти выделили на этот проект 5 млн норвежских крон. Были проведены масштабные работы: реставраторы восстановили несколько надгробных памятников, посадили и обработали деревья и цветы, починили пешеходные дорожки. Старое кладбище теперь является зелёным оазисом в городе, а также интересным историческим свидетельством развития погребальных памятников [7].

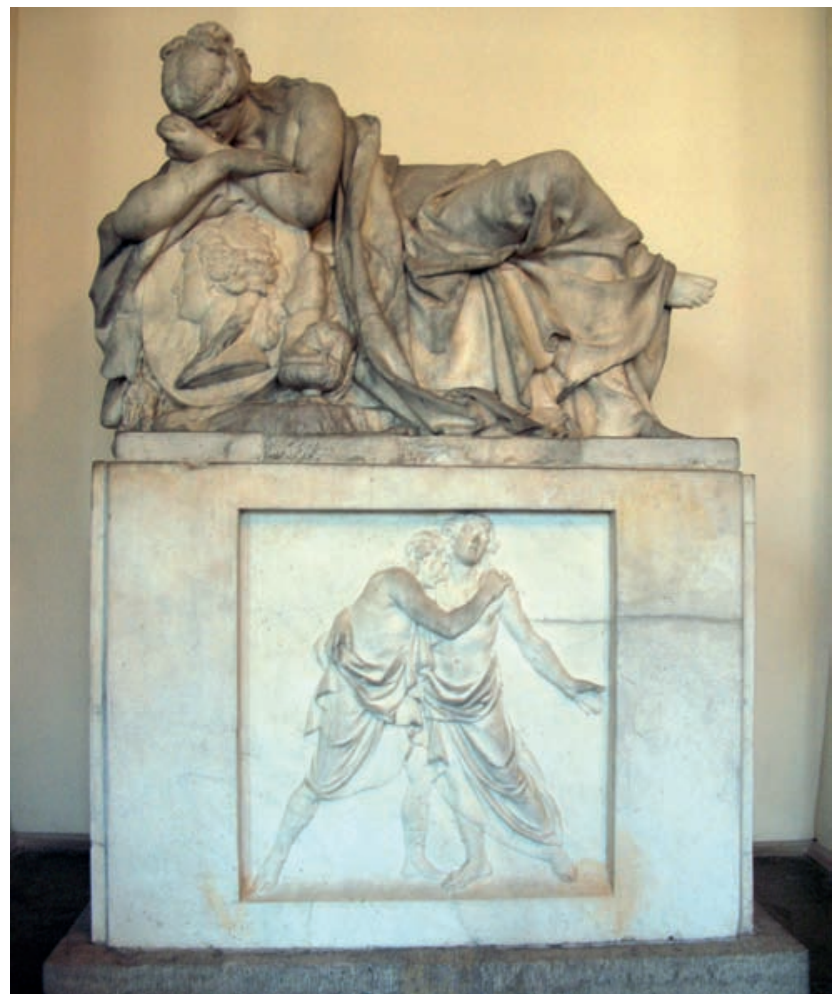

б) 
Похожая ситуация сложилась и в Германии. Рассматривая исторические кладбища в Берлине, нужно отметить, что здесь в связи с резким ростом населения уже в конце XIX века Берлинскому городскому синодальному объединению пришлось планировать создание центральных кладбищ у городских ворот. Были запланированы три больших кладбища, где каждый приход должен был иметь своё собственное кладбище, включённое в огромную структуру. 28 марта 1909 года состоялось официальное открытие Юго-Западного кладбища. Юго-Западное кладбище уже через несколько десятилетий превратилось в одно из самых больших и известных захоронений в Германии. На общее впечатление от кладбища определённо влияет не только наличие «великих могил», но и сочетание садового и кладбищенского искусства, архитектуры и скульптуры, здесь работали известнейшие архитекторы и художники. У кладбища непростая история, с середины XX века оно переживало сильнейший кризис и запустение, и только с 1991 года началось его восстановление. Сегодня большое количество посетителей говорит о том, что существует большой интерес к специфической культурной и художественной истории парка. А Юго-Западное кладбище ценится не только как место погребения и траура, но и приобретает всё большее значение как городское пространство и место встреч [8].

Мемориальная скульптура, изготовление художественных надгробий традиционно занимали важное место в истории итальянского искусства. И, конечно же, кладбища в Италии - это не только места погребения и скорби. Прогулки по ним сравнимы с посещением музея. Кроме того, например, в Парме, на кладбище Ла-Виллетта посетители часто слышат музыку, доносящуюся из секции, где находится могила Николо Паганини - это молодые скрипачи отдают дань уважения великому маэстро [9].

В дополнение к рассмотренному европейскому опыту стоит добавить, что исторические некрополи - это, действительно, музеи под открытым небом, по их коллекциям можно изучать архитектурные стили, развитие пластического искусства. Например, стиль первого кладбища Афин, раскинувшегося на склоне холма Ардитос, можно проследить до эпохи романтизма: памятники окружены кипарисами и соснами и вместе они запечатлевают образ, который действительно отражает природу Аттики. Коллекция скульптур, размещённая на кладбище, может рассматриваться как наиболее значительный и подлинный пример качества мраморной резьбы. Стелы, украшения,

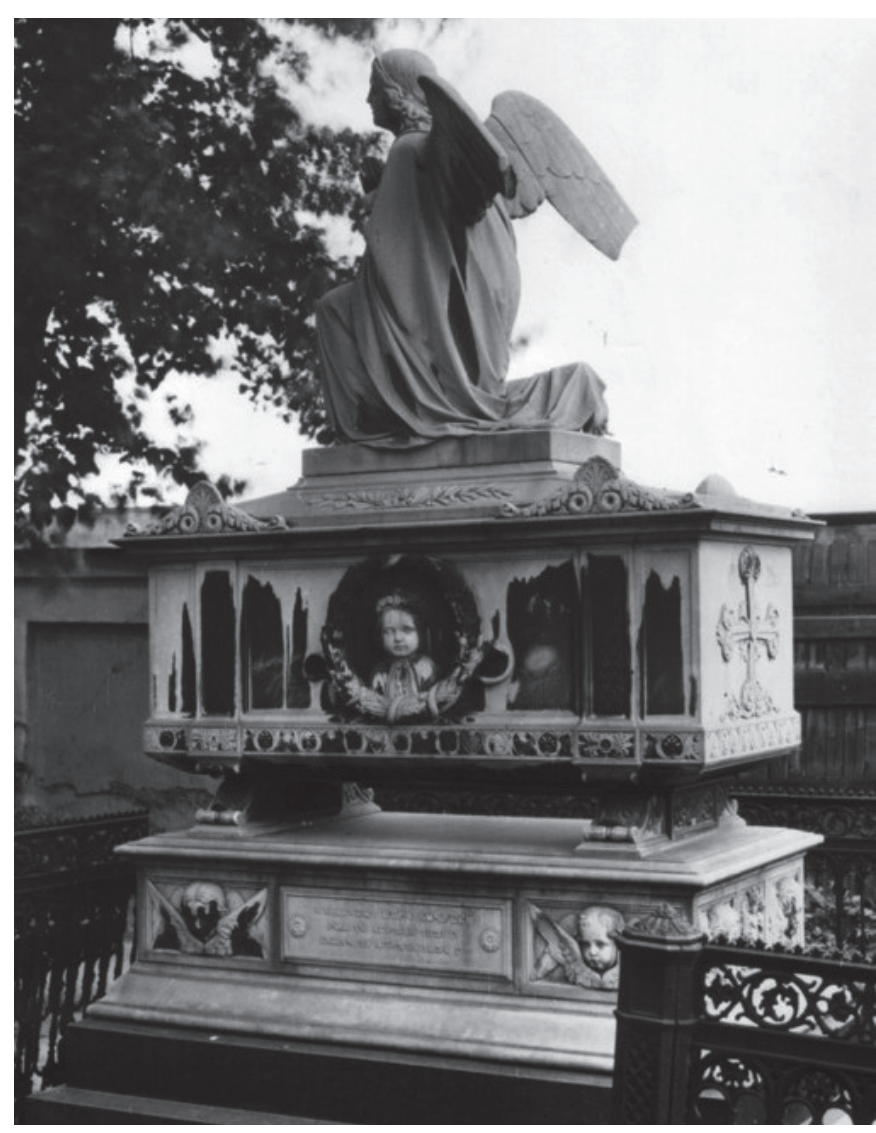

a)

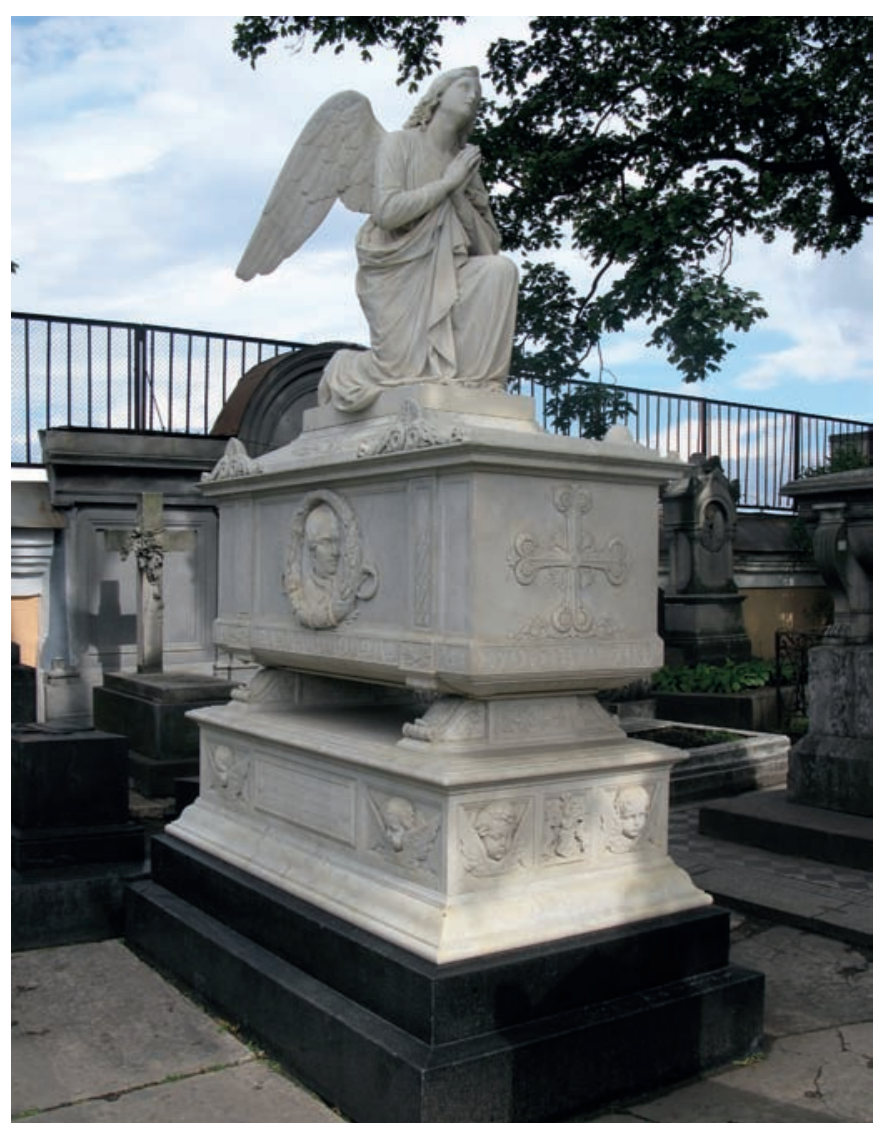

б)

Puс. 4. Надгробие Е.А. и В.Н. Кочубей: а) фото А. Григорьева (источник: фото № 4945/1. Нег. № 5472. Фотолаборатория Академии художеств (ССР. Ленинград 1970 г. Архив ГМГС); б) после комплексной реставрации. 2007 год 
часто встречающиеся на могилах, в основном происходят от древних моделей: как популярные мемориальные элементы они представлены в основном и в нескольких формах на кладбище, и здесь их больше, чем где-либо в мире. Помимо погребальных произведений искусства, основанных на древних моделях, можно найти некоторые образцы византийских и египетских узоров, а также значительное количество бронзовых шедевров [10].

Надгробные памятники на русских кладбищах - уникальные произведения русской мемориальной пластики, но, стоит отметить, что в России исторические некрополи прежде всего воспринимаются как место погребения, хотя и есть примеры, когда некрополь является частью музейной экспозиции, например, Музей городской скульптуры в Санкт-Петербурге. Представляется очевидным, что нахождение новых смыслов для пространств музейных некрополей в России - интересный и важный аспект для их сохранения, а составление концепций развития - отдельная тема для исследований.

\section{Лumepamypa}

1. Скульптура XVIII-XIX веков на открытом воздухе. Проблемы сохранения и экспонирования / Н.Н. Ефремова, Д.В. Осипов, В.В. Рытикова // Материалы Научно-практической конференции «Скульптура XVIII-XIX веков на открытом воздухе. Проблемы сохранения и экспонирования». СПБГУТД, 2010 г. - СПб, 2010.

2. The Effects of Air Pollution on Cultural Heritage / John Watt, Johan Tidblad, Vladimir Kucera, Ron Hamilton. - NewYork, USA, 2009. - 306 p.

3. Головин В.П. От амулета до монумента / В.П. Головин. - М. : МГУ, 1999. - 128 с.

4. Художественное надгробие в собрании Государственного музея городской скульптуры : Научный каталог. Т. 3. Некрополь XVIII в. / Составители А.А. Алексеев, Ю.М. Пирютко, В.В. Рытикова. - СПб : Гос. музей гор. скульптуры : Союз-Дизайн, 2005. ISBN 5-85952-015-8.

5. Восстановление памятников архитектуры Ленинграда. - Л. : Стройиздат. Ленинградское отделение, 1983. - С. 312.

6. Комплексный мониторинг состояния памятников из камня в городской среде (на примере Некрополя XVIII века Государственного музея городской скульптуры) / Н.Ф. Лепёшкина, О.В. Франк-Каменецкая, Д.Ю. Власов, В.В. Рытикова // Реликвия (Реставрация. Консервация. Музеи), 2005. - № 2 (9). - C. 20-25.

7. Mauro Felicori Historical cemeteries in a medieval city (Norway) / Mauro Felicori, Annalisa Zanotti // A Historical Heritage to Appreciate and Restore : A Guidebook to European Cemeteries. - Bologna : Comune di Bologna (SCENE Project), 2004. - 230 p. - p. 23-29.

8. Mauro Felicori. Art, architecture and sculptures in a forest-like monument / Mauro Felicori, Annalisa Zanotti // A Historical Heritage to Appreciate and Restore : A Guidebook to European Cemeteries. - Bologna : Comune di Bologna (SCENE Project), 2004. - 230 p. - p. 29-35.

9. Mauro Felicori. Young violinists play on Paganini's grave, in the cemetery «sponsored» by Duchess Marie Louise / Mauro Felicori, Annalisa Zanotti // A Historical Heritage to Appreciate and Restore : A Guidebook to European Cemeteries. - Bologna : Comune di Bologna (SCENE Project), 2004. - 230 p. - p. 121-127.

10. Mauro Felicori The historical cemetery of modern Greece / Mauro Felicori, Annalisa Zanotti // A Historical Heritage to Appreciate and Restore: A Guidebook to European Cemeteries. - Bologna : Comune di Bologna (SCENE Project), 2004. - 230 p. - p. 13-17.

\section{References}

1. Efremova N.N., Osipov D.V., Rytikova V.V., Timofeev V.N., Frank-Kamenetskaya 0.V. Skul'ptura XVIII-XIX vekov na otkrytom vozdukhe. Problemy sokhraneniya $i$ eksponirovaniya [Sculpture of the 18th-19th centuries in the open air. Problems of preservation and exhibiting]. In: Materialy nauchno-prakticheskoi konferentsii "Skul'ptura XVIII-XIX vekov na otkrytom vozdukhe. Problemy sokhraneniya $i$ eksponirovaniya" [Materials of the Scientific and Practical Conference "Sculpture of the 18th-19th centuries in the open air. Problems of preservation and exhibition"], SPBGUTD, 2010. SPb, SPBGUTD Publ., 2010. (In Russ.)

2. Watt John, Tidblad Johan, Kucera Vladimir, Hamilton Ron. The Effects of Air Pollution on Cultural Heritage. New York, USA, 2009, 306 p. (In Engl.)

3. Golovin V.P. Ot amuleta do monumenta [From amulet to monument]. Moscow, MGU Publ., 1999, 128 p., pp. 3-6. (In Russ.)

4. Khudozhestvennoe nadgrobie v sobranii Gosudarstvennogo muzeya gorodskoi skul'ptury. Nauchnyi katalog [Artistic gravestone in the collection of the State Museum of Urban Sculpture. Scientific catalog]. Vol. 3. Nekropol' XVIII v. [Necropolis of the 18th century]. Composed by A.A. Alekseev, Yu.M. Piryutko, V.V. Rytikova. St. Petersburg, State museum of mountains. Sculpture; Soyuz-Design Publ., 2005. ISBN 5-85952-015-8. (In Russ.)

5. Vosstanovlenie pamyatnikov arkhitektury Leningrada [Restoration of architectural monuments of Leningrad]. Leningrad, Stroiizdat, Leningrad branch Publ., 1983. (In Russ.)

6. Lepeshkina N.F., Frank-Kamenetskaya 0.V., Vlasov D.Yu., Rytikova V.V. Kompleksnyi monitoring sostoyaniya pamyatnikov iz kamnya $\vee$ gorodskoi srede (na primere Nekropolya XVIII veka Gosudarstvennogo muzeya gorodskoi skul'ptury) [Comprehensive monitoring of the state of stone monuments in the urban environment (on the example of the 18th century Necropolis of the State Museum of Urban Sculpture)]. In: Relikviya (Restavratsiya. Konservatsiya. Muzei) [Relic (Restoration. Conservation. Museums)] no. 2 (9), pp. 20-25. 
7. Mauro Felicori, Annalisa Zanotti. Historical cemeteries in a medieval city (Norway). In: A Historical Heritage to Appreciate and Restore: A Guidebook to European Cemeteries. Bologna, Comune di Bologna (SCENE Project) Publ., 2004, pp. 23-29.

8. Mauro Felicori, Annalisa Zanotti. Art, architecture and sculptures in a Restore : A Guidebook to European Cemeteries. Bologna, Comune di Bologna (SCENE Project) Publ., 2004, pp. 29-35.

9. Mauro Felicori, Annalisa Zanotti. Young violinists play on Paga-nini's grave, in the cemetery "sponsored" by
Duchess Marie Louise. In: «A Historical Heritage to Appreciate and Restore : A Guidebook to European Cemeteries. Bologna, Comune di Bologna (SCENE Project) Publ., 2004, pp. 121-127.

10. Mauro Felicori, Annalisa Zanotti. The historical cemetery of modern Greece. In: A Historical Heritage to Appreciate and Restore: A Guidebook to European Cemeteries. Bologna, Comune di Bologna (SCENE Project) Publ., 2004, pp. 13-17.

Логинова Юлия Алексеевна (Москва). ФГОУ В0 «Московский архитектурный институт (Государственная академия) (107031, Москва, Рождественка, 11/4. МАРХИ).Эл. почта: loginova_rest@mail.ru.

Loginova A. Yulia (Moscow). Moscow Institute of Architecture (State Academy) (11 Rozhdestvenka st, Moscow, 107031. MARKHI). E-mail: loginova_rest@mail.ru. 